CZASOPISMO INŻYNIERII LĄDOWEJ, ŚRODOWISKA I ARCHITEKTURY JOURNAL OF CIVIL ENGINEERING, ENVIRONMENT AND ARCHITECTURE

JCEEA, t. XXXIV, z. 64 (4///17), październik-grudzień 2017, s. 267-276, DOI:10.7862/rb.2017.211

Tadeusz NOCH ${ }^{1}$

\title{
TERMODYNAMICZNE CZYNNIKI ROBOCZE STOSOWANE W POMPACH CIEPLA
}

\begin{abstract}
$\mathrm{W}$ opracowaniu pt. Termodynamiczne czynniki robocze stosowane w pompach ciepła opisano geotermię niskotemperaturową. Przedstawiono podstawowy podział pomp ciepła. Scharakteryzowano czynniki robocze stosowane w pompach ciepła. Omówiono przeprowadzone badania dotyczące stosowanych w technice cieplnej czynników z grupy CFC i HCFC. W szczególności analizą objęto harmonogram wycofania z użytku czynników chlorowcowopochodnych zakwalifikowanych do ww. grupy. Uwzględniono w analizie wskaźniki ekologiczne niektórych czynników chłodniczych. Pokazano, że wskaźnik ekologiczny ODP charakteryzuje wpływ danego czynnika na intensywność rozkładu ozonu. Natomiast GWP opisuje wpływ czynnika na potęgowanie efektu cieplarnianego. Z kolei TEWI jest wskaźnikiem umożliwiającym ocenę globalnego ocieplenia atmosfery, spowodowanego eksploatacją pompy ciepła lub urządzenia chłodniczego. Zwrócono uwagę na sposób obliczania wartości wskaźnika TEWI. Wyspecyfikowano podstawowe właściwości najczęściej stosowanych zamienników R22. Wskazano na zmianę parametrów eksploatacyjnych pomp ciepła spowodowaną wprowadzeniem nowych czynników roboczych. W niniejszym opracowaniu podano również niezbędne kryteria uwzględniane w procesie badań i oceny przydatności czynników roboczych do pracy $\mathrm{w}$ obiegu pomp ciepła. Odniesiono się do efektywności energetycznej w przypadku eksploatacji pomp ciepła z wykorzystaniem źródeł niskotemperaturowych powodujące redukcję emisji $\mathrm{CO}_{2}$. W badaniu ustalono poziom korzystnego wpływu tej emisji w porównaniu z potencjałem konwencjonalnych źródeł energii. Szczególną uwagę zwrócono na technologiczne rozwiązania w zakresie minimalizacji zawartości czynnika roboczego w instalacji, związanego z ograniczeniem jego emisji do atmosfery. Przewody obiegu czynnika roboczego, łącząc poszczególne elementy i urządzenia, tworzą zamkniętą instalację pompy ciepła. W montażu miedzianych instalacji pomp ciepła stosowane są specjalne rury miedziane przeznaczone do chłodnictwa i klimatyzacji.
\end{abstract}

Słowa kluczowe: ekologia, środowisko, technika cieplna, czynniki z grupy CFC i HCFC, wskaźniki ekologiczne, czynniki chłodnicze, ozon, współczynnik wydajności grzejnej COP, wskaźnik ekologiczny ODP, GWP i TEWI

\footnotetext{
${ }^{1}$ Tadeusz Noch, Gdańska Szkoła Wyższa, Wydział Nauk Inżynierskich, ul. Biskupia 24B, 80-875 Gdańsk; tel. 602130 709; tadeusz.noch@gsw.gda.pl
} 


\section{Wstęp}

Wykorzystanie ciepła ze źródeł odnawialnych jest jednym z nowoczesnych i efektywnych sposobów poszanowania energii i ochrony środowiska. Problemy współczesnej energetyki rozwiązywane są poprzez promowanie i wdrażanie nowych technologii pozyskiwania i przetwarzania energii oraz poprzez racjonalizację jej wykorzystania. Przykładem jest wykorzystanie energii ze źródeł odnawialnych, takich jak powietrze, grunt, wody powierzchniowe i gruntowe, za pomocą pomp ciepła.

Międzynarodowa Agencja Energetyczna (IEA) przyjęła, definicję dotyczącą energii odnawialnej, określoną przez Grupę Roboczą ds. Odnawialnych Nośników Energii. Zdefiniowano, że odnawialna energia jest tą ilością energii, która jest pozyskiwana $\mathrm{w}$ naturalnych procesach przyrodniczych stale odnawialnych. Zakres tej definicji obejmuje np. energię słoneczną, wiatrowe, z biomasy, geotermalną, cieków wodnych oraz biopaliwa i wodór.

Zasady wykorzystania energii ze źródeł odnawialnych w krajach członkowskich UE reguluje Dyrektywa Parlamentu Europejskiego i Rady 2009/28/WE z dnia 23 kwietnia 2009 roku w sprawie promowania stosowania energii ze źródeł odnawialnych. Dyrektywa ta ustanawia wspólne ramy promowania energii ze źródeł odnawialnych [1].

\section{Geotermia niskotemperaturowa}

Źródła energii geotermicznej klasyfikuje się w zależności od stanu skupienia nośnika ciepła i jego temperatury. W klasyfikacji tej rozróżnia się: grunty i skały do głębokości $2500 \mathrm{~m}$, przypowierzchniowe wody gruntowe, gorące i ciepłe wody wgłębne, para wodna, wysady solne oraz gorące skały [2]. Płyny geotermalne, wypełniające zbiorniki naturalnych basenów sedymentacyjnostrukturalnych, mają różną temperaturę. Polska zalicza się do krajów, które posiadają bogate zasoby wód geotermalnych o średniej entalpii.

Badania wykazały, że na obszarze Polski znajduje się około $6500 \mathrm{~km}^{3}$ wód termalnych o temperaturze ok. $30 \div 120^{\circ} \mathrm{C}$. Najbardziej korzystne warunki do eksploatacji wód geotermalnych znajdują się w okręgu szczecińsko-łódzkim [3, 4].

W Polsce, jako umowną granicę pomiędzy wodami termalnymi a niskotemperaturowymi przyjmuje się temperaturę $20^{\circ} \mathrm{C}$. Temperatura nośnika ciepła, wynosząca $20^{\circ} \mathrm{C}$, jest mierzona na wypływie z otworu wiertniczego. Została ona formalnie przyjęta za wartość graniczną, od której Prawo geologiczne i górnicze uznaje wody podziemne za termalne [5]. 


\section{Podstawy dzialania pomp ciepla}

W pompie ciepła zachodzi proces podnoszenia potencjału cieplnego. Występuje proces pobierania ciepła ze źródła o niższej temperaturze $T_{o}$ i przekazywania go do źródła o temperaturze wyższej $T_{g}[6]$.

W sprężarkowej pompie ciepła transformacja ciepła urzeczywistniona jest za pomocą czynnika roboczego, który krążąc w zespole urządzeń, poddawany jest ciągowi przemian. Zjawisko to tworzy tzw. lewobieżny obieg Lindego. Instalację sprężarkowej pompy ciepła tworzą: dolne źródło ciepła (źródło ciepła niskotemperaturowego), sprężarkowa pompa ciepła, górne źródło ciepła (instalacje odbiorcze).

W procesie technologicznym przesyłu ciepła za pomoca pompy ciepła wykorzystywany jest czynnik roboczy. Ideowy schemat instalacji sprężarkowej pompy ciepła oraz zmiany fazy czynnika roboczego w instalacji pompy ciepła pokazuje rys. $1[6]$.

a)

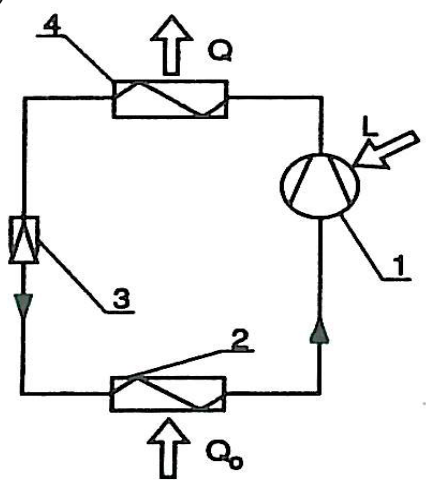

b)

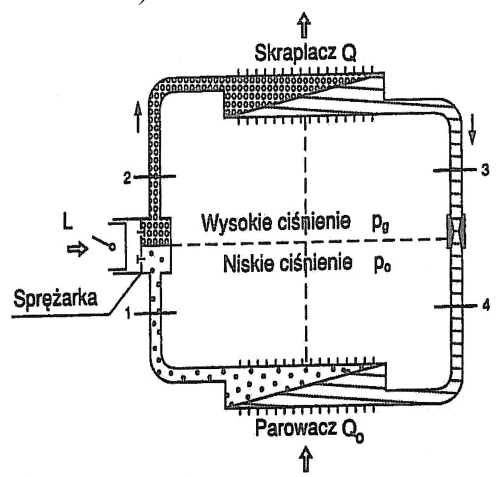

Rys. 1. Ideowy schemat instalacji sprężarkowej pompy ciepła oraz zmiana fazy czynnika roboczego - schemat ideowy instalacji (a); zmiany fazy czynnika roboczego (b), na podstawie [6]

schemat ideowy instalacji: 1 - agregat sprężarkowy, 2 - parowacz, 3 - zawór rozprężny, 4 - skraplacz

Fig. 1. Schematic diagram of heat pump compressor installation and the change of phase of a heat exchanger - schematic diagram of installation (a); change of a phase of a heat exchanger (b), based on [6]

schematic diagram of installation: 1 - compressor, 2 - evaporator, 3 - expansion valve, 4 - condenser

Badając funkcjonowanie sprężarkowej pompy ciepła można stwierdzić, że efektem jej działania jest wykorzystanie ciepła przegrzania i ciepła skraplania pary czynnika roboczego do podgrzania nośnika ciepła w instalacji odbiorczej.

Energetyczny bilans pompy ciepła przedstawia wzór (1), zaś teoretyczny współczynnik wydajności grzejnej $C O P_{t}$ - wzór (2).

$$
Q=Q_{o}+L
$$




$$
C O P_{t}=C O P_{L}=\frac{Q_{o}+L}{L}=1+\frac{Q_{o}}{L}
$$

gdzie: $Q$ - ilość ciepła uzyskanego w skraplaczu, kJ,

$Q_{o}$ - ilość ciepła pobranego w parowaczu, kJ,

$L$ - praca dostarczona do sprężarki, kJ.

Odnosząc wielkości występujące w równaniu (2) do 1 kg czynnika roboczego krążącego w obiegu otrzymamy:

$$
q=q_{o}+l
$$

oraz

$$
C O P_{t}=C O P_{L}=\frac{q}{l}
$$

gdzie: $q$ - właściwa wydajność grzejna obiegu, $\mathrm{kJ} / \mathrm{kg}$,

$l$ - właściwa praca sprężania w obiegu, $\mathrm{kJ} / \mathrm{kg}$,

$q_{o}-$ jednostkowa ilość ciepła pobranego w parowaczu z dolnego źródła, $\mathrm{kJ} / \mathrm{kg}$.

\section{Czynniki robocze w pompach ciepla}

Czynnikiem roboczym, stosowanym w pompach ciepła jest czynnik termodynamiczny, który podczas obiegu pośredniczy w przekazywaniu ciepła ze źródła dolnego do źródła górnego (odbiornika). Od właściwości czynnika roboczego zależą rodzaj konstrukcji pompy ciepła i zużycie energii napędowej. W początkowej fazie rozwoju techniki chłodniczej i pomp ciepła stosowano czynniki naturalne jak np. amoniak. Z uwagi na niekorzystne właściwości amoniaku (toksyczność, wybuchowość, korozyjne działanie na miedź i jej stopy) uniemożliwiały szersze jego zastosowanie w urządzeniach klimatyzacyjnych, chłodniczych i pompach ciepła. Później wyprodukowano syntetyczne czynniki chłodnicze, zwane freonami. Czynniki te występowały jako chlorowcowopochodne węglowodorów nasyconych i nienasyconych. Freony były nietoksyczne, niepalne i nieagresywne w stosunku do miedzi. Zastosowano je w technice, $\mathrm{z}$ uwagi na możliwość budowy automatycznych, hermetycznych urządzeń chłodniczych i pomp ciepła. Najczęściej stosowane są syntetyczne czynniki robocze, pochodne węglowodorów nasyconych i nienasyconych. W oparciu o budowę chemiczną czynnika termodynamicznego wprowadzono jednolity system nazewnictwa czynników chłodniczych, tj. czynników roboczych w pompach ciepła. System ten później stał się standardem ISO. Oznaczenie czynnika chłodniczego składa się z kilku symboli, których znaczenie jest związane z ich wartością i pozycją w nazwie [7].

W zależności od budowy cząsteczki, czynniki chłodnicze i robocze przyporządkowuje się do odpowiedniej grupy związków chemicznych, np. [6]: 
- CFC - chlorofluorowęglowodory; oznaczenie w pełni halogenowych związków węgla, w których wszystkie atomy wodoru w cząsteczce zostały zastąpione atomami chloru i fluoru; charakteryzuje je duża stabilność chemiczna,

- HCFC - wodorochlorofluorowęglowodory; oznaczenie substancji organicznych, w których nie wszystkie atomy wodoru w cząsteczce zostały zastąpione przez atomy chloru i fluoru,

- HFC - hydrofluorowęglowodory; oznaczenie substancji organicznych, w cząsteczkach których część atomów wodoru została zastąpiona atomami fluoru.

Ze względu na ochronę środowiska stosowane są coraz częściej czynniki robocze będące dwu lub trójskładnikowymi roztworami. Tworzą one grupę tzw. czynników zeotropowych, gdyż podczas izobarycznych procesów wrzenia lub skraplania zmienia się temperatura. Procesy te nie są izotermiczne i występuje w nich tzw. poślizg temperaturowy $\Delta T_{g}$ (różnica między temperaturą pary suchej nasyconej a temperaturą wrzenia roztworu w warunkach tego samego ciśnienia). Do najczęściej używanych w pompach ciepła czynników zeotropowych zalicza się: R 404A, R 407C, R 410A.

Badania wykazały, że stosowanie w technice cieplnej czynników z grupy CFC i HCFC szkodzi środowisku poprzez degradację ozonu stratosferycznego (freony są rozkładane a chlor niszczy ozon). Dla ograniczenia negatywnych skutków związków CFC i HCFC wprowadzono międzynarodowe regulacje prawne. Zorganizowana Konferencja Wiedeńska dotyczyła ochrony stratosferycznej warstwy ozonowej. Skutkiem tej konferencji było przejęcie Protokołu Montrealskiego, który wszedł w życie 1 stycznia 1989 roku. Polska jest sygnatariuszem obu porozumień. Protokół Montrealski zawiera szczegółowy harmonogram wycofania z użytku czynników chlorowcowopochodnych, tj. grupa CFC i HCFC. Harmonogram wycofania czynników HCFC pokazuje rys. 2 [8].

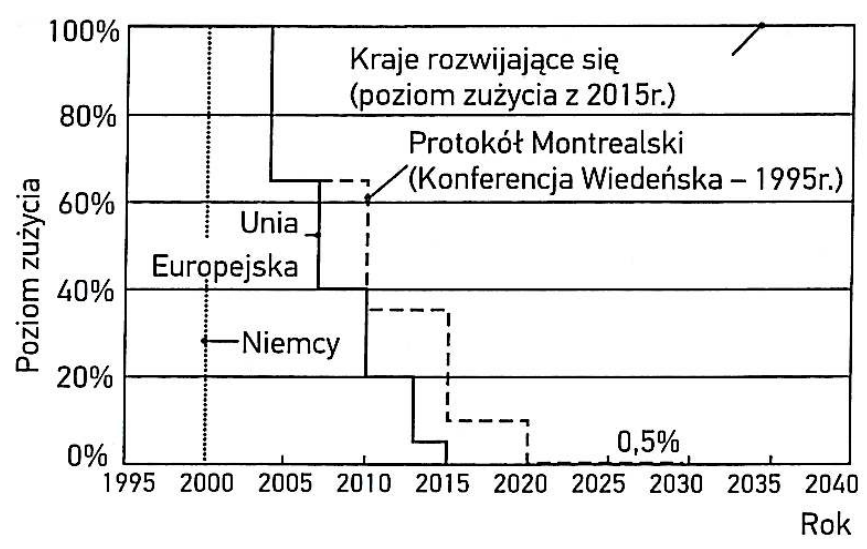

Rys. 2. Harmonogram wycofania czynników HCFC, na podstawie [8]

Fig. 2. Schedule of HCFC exchangers withdrawal, based on [8] 
Z analiz wynika, że Protokół Montrealski stanowi początek wycofania z użytku substancji zubożających warstwę ozonową (chlorofluorowęglowodorów oraz wodorochlorofluorowęglowodorów). Natomiast w Polsce sprawy dotyczące eksploatacji urządzeń napełnianych czynnikami HCFC reguluje Ustawa z dnia 15 maja 2015 roku o substancjach zubożających warstwę ozonową oraz o niektórych fluorowanych gazach cieplarnianych [9]. W Polsce postanowienia Protokołu Montrealskiego są realizowane ustawowo, wobec czego zakazano stosowania czynników CFC w nowych instalacjach chłodniczych; istnieje również zakaz serwisowania oraz handlu tymi urządzeniami. W Europie przyjęto działania, mające na celu znaczną redukcję zużycia tych substancji do celów techniki chłodniczej [10].

Odnośnie substancji zubożających warstwę ozonową podjęto decyzję o wycofaniu z użycia czynników z grupy HCFC. W powyższej sprawie określony został szczegółowy kalendarz ich wycofania zawarty w postanowieniach Dyrektywy Europejskiej [11].

Od 1 stycznia 2010 roku wprowadzony został zakaz importu, dystrybucji oraz stosowania wodorochlorofluorowodorów. Natomiast od 1 stycznia 2015 roku zakaz ten obejmuje wszystkie wodorochlorofluorowęglowodory $\mathrm{w}$ tym również substancje z odzysku. Z analizy wynika, że w krajach Unii Europejskiej instalacje chłodnicze i klimatyzacyjne napełnione czynnikami HCFC, głównie R22 podlegają wymianie, modernizacji lub należy poddać procesowi wymiany czynnika i zastąpienia go alternatywną substancją, nieszkodliwą w stosunku do warstwy ozonowej [12].

Problemy związane z wycofaniem czynników HCFC mogą być rozwiązywane $\mathrm{z}$ uwzględnieniem określonych wariantów:

- całkowita wymiana urządzeń napełnionych R22 na inne: napełnione czynnikami naturalnymi (R717, R744, R290 itd.) oraz czynnikami syntetycznymi (R407C, R410A, R422D, R507 itd.),

- przezbrojenie całych urządzeń na czynniki z grupy HFC: R407C, R404A, R507,

- zastąpienie R22 czynnikami z grupy HFC: R134a, R417A, R419A, R422A, R422D, R427A,

- serwisowanie urządzeń napełnionych R22 tak długo, jak to jest możliwe.

Do oceny wpływu czynników chłodniczych na środowisko stosowane są trzy wskaźniki ekologiczne:

- potencjał niszczenia ozonu ODP - Ozon Depletion Potential,

- globalny potencjał ocieplenia GWP - Global Warming Potential,

- całkowity równoważny wskaźnik ocieplenia TEWI - Total Equivalent Warming Impact.

Wskaźniki ekologiczne niektórych czynników chłodniczych przedstawia tabela $1[6]$. 
Tabela 1. Wskaźniki ekologiczne niektórych czynników chłodniczych, na podstawie [6]

Table 1. Ecological indicators of some refrigerants, based on [6]

\begin{tabular}{|c|c|c|c|c|c|c|}
\hline \multirow{2}{*}{ Lp. } & \multicolumn{2}{|c|}{ Czynnik chłodniczy } & \multirow{2}{*}{$\begin{array}{l}\text { Normalna } \\
\text { temperatura } \\
\text { wrzenia }\left({ }^{\circ} \mathrm{C}\right)\end{array}$} & \multicolumn{2}{|c|}{$\begin{array}{l}\text { Wskaźniki } \\
\text { ekologiczne }\end{array}$} & \multirow{2}{*}{$\begin{array}{c}\text { Żywotność } \\
\text { w atmosferze, } \\
\text { lata }\end{array}$} \\
\hline & Grupa & Oznaczenie & & ODP & GWP & \\
\hline 1 & $\mathrm{CO}_{2}$ & R744 & -40 & 0,0 & 1,0 & - \\
\hline 2 & $\mathrm{CFC}$ & $\mathrm{R} 12$ & -30 & 1,0 & 7300 & 120 \\
\hline 3 & HCFC & R22 & -41 & 0,055 & 1500 & 15,3 \\
\hline 4 & HFC & R134a & -26 & 0,0 & 1200 & 15,3 \\
\hline
\end{tabular}

Wskaźnik ekologiczny $O D P$ charakteryzuje wpływ danego czynnika na intensywność rozkładu ozonu. Wartość tego wskaźnika jest odniesiona do właściwości R11. $O D P_{R 11}=1$. Dla naturalnych czynników chłodniczych $O D P=0$. Drugi wskaźnik ekologiczny GWP opisuje wpływ czynnika na potęgowanie efektu cieplarnianego. Wartości tego wskaźnika odniesione są do właściwości dwutlenku węgla R744 i horyzontu czasowego oddziaływania danej substancji (wynoszącego 100 lat), $G W P_{R 744}=1$. Kolejny wskaźnik ekologiczny $T E W I$ jest to całkowity równoważny wskaźnik ocieplenia. TEWI jest wskaźnikiem umożliwiającym ocenę globalnego ocieplenia atmosfery, spowodowanego eksploatacją pompy ciepła lub urządzenia chłodniczego. Wskaźnik ten uwzględnia bezpośredni wpływ czynników wypływających przez nieszczelności instalacji oraz pośredni udział energii wymaganej do zasilania urządzeń przez cały okres eksploatacji. TEWI ma istotne znaczenie w przypadku porównywania alternatywnych urządzeń lub czynników roboczych. Uzależnione jest to od warunków takiego samego zastosowania i tego samego usytuowania. Wartość wskaźnika TEWI oblicza się za pomocą wzoru:

$$
T E W I=G W P \cdot L \cdot n+n \cdot E_{a} \cdot \beta
$$

gdzie: TEWI - całkowity równoważny wskaźnik ocieplenia, [ $\left.\mathrm{kg} \mathrm{CO}_{2}\right]$,

$G W P$ - globalny potencjał ocieplenia czynnika roboczego,

$L$ - roczne straty czynnika przez nieszczelności, [kg/a],

$n$ - czas eksploatacji urządzenia, [a],

$E_{a}$ - roczne zużycie energii napędowej, [kWh/a],

$\beta$ - wskaźnik emisji $\mathrm{CO}_{2} \mathrm{w}$ procesie wytwarzania $1 \mathrm{kWh}$ energii napędowej, $\left[\mathrm{kgCO}_{2} / \mathrm{kWh}\right]$, przy czym

$G W P \cdot L \cdot n$ - wpływ bezpośredniej emisji czynnika roboczego,

$n \cdot E_{a} \cdot \beta$ - wpływ zużycia energii napędowej.

Wskaźnik TEWI oblicza się nie tylko w stosunku do samego czynnika roboczego lecz w odniesieniu do określonej pompy ciepła lub urządzenia chłodniczego. Wskaźnik ten ulega zmianie w zależności od rodzaju urządzenia i zależy 
od wartości parametrów przyjętych w założeniach. W szczególności są to parametry, do których zalicza się czas działania, trwałość eksploatacyjna, efektywność obiegu i jego sprawność.

Obowiązujące przepisy, dotyczące ochrony stratosferycznej warstwy ozonowej, zabraniają stosowania nowych pomp ciepła napełnionych R22 (HCFC22). Potencjał niszczenia ozonu R22 wynosi $O D P=0,055$.

Analizując omawianą problematykę zauważa się, że czynnik R410A jest długoterminowym zamiennikiem R22 w klimatyzatorach, domowych i handlowych urządzeniach chłodniczych, pompach ciepła, a także w nowo projektowanych układach chłodniczych w przemyśle i supermarketach. Czynnik ten znajduje również zastosowanie w układach niskotemperaturowych, w których stosowano dotychczas czynnik R13B1, należący do grupy czynników CFC [13].

$\mathrm{Na}$ szczególną uwagę zasługuje fakt, że wymiana czynnika roboczego w pompie ciepła lub chłodziarce spowoduje zmianę ich osiągów, tj. mocy grzewczej i chłodniczej. Nastąpi również zmiana wskaźnika efektywności energetycznej. Względna zmiana wartości $C O P$ różnych zamienników R22 pokazana jest na rysunku 3 [14].

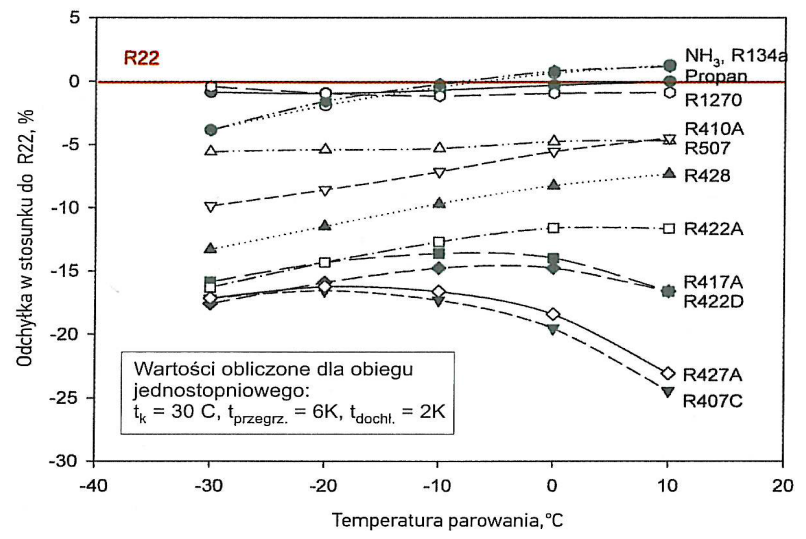

Rys. 3. Względna zmiana wartości COP różnych zamienników R22, na podstawie [14]

Fig. 3. Relative changes of COP for different R22 replacements, based on [14]

Przy ocenie przydatności czynników roboczych do pracy w obiegu pomp ciepła należy uwzględnić pewne ustalone kryteria. Do nich zalicza się wartość współczynnika wydajności grzejnej $C O P$ oraz wartość i zakres ciśnienia nasycenia. Jako kolejne kryterium przyjęto objętościową wydajność grzejną. W analizowanym zakresie istotne znaczenie ma wpływ na środowisko tzw. ekologia, która dotyczy wartości wskaźników ekologicznych $O D P, G W P$ oraz TEWI. 


\section{Zakończenie}

Analizując czynnik roboczy w obiegu pompy ciepła zauważa się, że wartość wskaźnika globalnego potencjału ocieplenia GWP czynnika roboczego zastosowanego w obiegu pompy ciepła nie może przekraczać $I T H=100$ lat, wartość $G W P=2000$. W przypadku, gdy wartość $G W P$ czynnika jest niższa niż $150, \mathrm{np} . G W P<150$, to wartości podanych wskaźników $C O P, E E R$ i PER należy zmniejszyć o $15 \%$. W instalacji pozyskiwania ciepła niskotemperaturowego stosowane nośniki ciepła nie mogą być substancjami niebezpiecznymi, co reguluje Dyrektywa Rady 67/548/EWG.

W procesie budowy pomp ciepła należy uwzględnić obowiązujące wymagania, w szczególności dotyczące minimalizacji zawartości czynnika roboczego w instalacji. Przy zastosowaniu czynników syntetycznych chodzi o minimalizację ich emisji do atmosfery. Natomiast w przypadku amoniaku wprowadzone wymagania związane są względami bezpieczeństwa [6].

Przewody obiegu czynnika roboczego łączą poszczególne elementy i urządzenia. Tworzą zamkniętą instalację pompy ciepła. W pompach ciepła z syntetycznymi czynnikami roboczymi instalacja wykonywana jest, w zależności od średnicy, $\mathrm{z}$ rur stalowych lub bezkwasowych rur miedzianych. W technologiach związanych $\mathrm{z}$ montażem miedzianych instalacji pomp ciepła stosowano rury miedziane, spełniające wymagania normy PN-EN 12735-1:2000 Miedź i stopy miedzi.

\section{Literatura}

[1] Dyrektywa parlamentu Europejskiego i Rady 2009/28/WE z dnia 23 kwietnia 2009 roku w sprawie promowania stosowania energii ze źródeł odnawialnych.

[2] Sobański R., Kabat M.: Sposoby zagospodarowania niskotemperaturowych źródeł ciepła w ogrzewnictwie scentralizowanym. The International Conference of Air Conditioning \& District Heating, Wrocław-Szklarska Poręba 1998.

[3] Sobański R.: Energetyka geotermalna. Ekspertyza „Ekologiczne aspekty przetwarzania energii”. Wyd. Polska Akademia Nauk, Wydział IV Nauk Technicznych. Warszawa 1996.

[4] Górecki W.: Atlas zasobów energii geotermalnej na Niżu Polskim. Wyd. GEOS, Kraków 1995.

[5] Kapuściński J, Rodzoch A.: Geotermia niskotemperaturowa w Polsce - stan aktualny i perspektywy rozwoju, Warszawa 2006.

[6] Rubik M.: Pompy ciepła w systemach geotermii niskotemperaturowej. Wyd. MULTICO Oficyna Wydawnicza, Warszawa 2011.

[7] Europejska Komisja Międzynarodowego Komitetu Chłodnictwa - jednolity system nazewnictwa czynników chłodniczych (czynników roboczych w pompach ciepła).

[8] Bonca Z. i inni: Nowe czynniki chłodnicze i nośniki ciepła. Własności cieplne, chemiczne i użytkowe. Wyd. IPPU MASTA, Gdańsk 2004. 
[9] Ustawa z dnia 15 maja 2015 r. o substancjach zubożających warstwę ozonową oraz o niektórych fluorowanych gazach cieplarnianych (Dz.U. poz. 881).

[10] Report of the Refrigeration, Air Conditioning and Heat Pumps Technical Options Committee, UNEP. Nairobi, Kenya, January 2003.

[11] Dyrektywa Europejska 2037/2000/UE w sprawie substancji zubożających warstwę ozonową - kalendarz wycofania z użycia czynników z grupy HCFC.

[12] Skrzypulec W.: Retrofit - konieczność czy wolny wybór. Chłodnictwo \& Klimatyzacja 9/2008.

[13] Gutkowski M., Butrymowicz D.J.: Chłodnictwo i klimatyzacja. Wyd. WTN, Warszawa 2012.

[14] Eckhoff W., Flor F., Puhl Ch.: Zamiennik R22 - o czym należy pamiętać - cz. 1. Chłodnictwo \& Klimatyzacja 12/2008.

\section{THERMODYNAMIC HEAT EXCHANGERS USED IN HEAT PUMPS}

\section{S u m m a r y}

In the article entitled "Thermodynamic heat exchangers used in heat pumps" lowtemperature geothermal energy was described. Basic classification of heat pumps was presented. Heat exchangers and the research concerning heat exchangers representing groups CFC and $\mathrm{HCFC}$, which are used in the heat technology, were described. In particular, the schedule of withdrawal from use chlorine-derived exchangers, which belong to the latter groups, was analyzed. Ecologic indicators of some refrigerants were taken into account. It was presented that ecologic indicator ODP illustrates the influence of a certain refrigerant on an intensity of ozone decomposition. GPW indicates the influence of a certain refrigerant on the greenhouse effect. TEWI is an indicator which allows to assess global warming of the atmosphere, caused by heat pumps or refrigerating equipment. It was especially highlighted how the TEWI indicator is calculated. Basic features of most commonly used R22 replacements were specified. It was shown how exploitation parameters of heat pumps change if new heat exchangers are applied. In the article, the most significant criteria of heat exchanger evaluation in terms of their applicability in the heat pump loop were presented. The energetic efficacy of the heat pump exploitation using low-temperature geothermal energy and its $\mathrm{CO}_{2}$ emission reduction was mentioned. The results of the research establish the level of positive influence of this kind of emission in comparison with conventional sources of energy. Particular attention was paid to the technological solutions in the field of minimization the amount of heat exchanger in the installation, related to the reduction of its emission to the atmosphere. Pipes for heat exchanger circuit connect all modules and devices, creating closed installation of heat pump. In the installation process of copper heat pump systems, special copper pipes, dedicated to refrigeration and air conditioning, are used.

Keywords: ecology, environment, heat technology, exchangers from groups $\mathrm{CFC}$ and $\mathrm{HCFC}$, ecological indicators, refrigerants, ozone, coefficient of performance COP, ecologic indicator ODP, GWP, TEWI

Przestano do redakcji: 11.05.2017 $r$.

Przyjęto do druku: 15.12.2017 r. 